\title{
Factors related to the performance of Specialized Dental Care Centers
}

Flávia Christiane de Azevedo Machado ${ }^{1}$

Janmille Valdevino Silva ${ }^{1}$

Maria Ângela Fernandes Ferreira ${ }^{2}$

${ }^{1}$ Instituto Federal de Educação, Ciência e Tecnologia do Rio Grande do Norte. Av. Senador Salgado Filho 1559, Tirol. 59015-000 Natal RN Brasil.flavitamachado@ yahoo.com.br ${ }^{2}$ Odontologia Natal, Universidade Federal do Rio Grande do Norte.

\begin{abstract}
The Specialized Dental Care Centers (SDCC) have the mission to expand access to public medium complexity dental care and support the primary health care actions at this level of complexity. However, it is necessary to ensure the quality of services and to evaluate such services continuously to identify weaknesses and strengths that support the processes of leadership/management. Nevertheless, there is a dearth of studies on the assessment of oral health in specialized care that may indicate which factors should be investigated. Therefore, this integrated literature review sought to explore the plethora of publications on the evaluation of SDCC in the LILACS and MEDLINE data bases in October 2013 to identify factors possibly related to the performance of such health services. Thus, 13 references were included in this review pointing to forms of organization and management of work processes related to the creation of healthcare networks (operation of regulation centers and setting up of health consortiums). They include the contextual characteristics of the places where SDCCs are located (population size, Family Health Strategy coverage, Municipal Human Development Index, governance, governing capacity) were factors that influenced the SDCCs performance.
\end{abstract}

Key words Secondary health care, Oral health, Health evaluation, Health services assessment 


\section{Introduction}

The Brazil's National Oral Health Policy (BNOHP), Smiling Brazil, implemented in 2004, comprises, in the individual and collective spheres, a set of actions for promotion of health, prevention of diseases, diagnosis, treatment and rehabilitation ${ }^{1,2}$. Generally speaking, the larger goal of BNOHP is social inclusion, expanding access to dental care to all Brazilians ${ }^{1}$. For both, such a policy has six axes structuring: reorganization of primary oral health care, with magnification of oral health teams in the family health strategy; expansion and qualification of specialized attention; assistance in tertiary attention; promotion and prevention; restructuring and qualification; surveillance, monitoring and evaluation ${ }^{3}$.

In this sense of qualification and expansion of public dental assistance of medium complexity, the Dental Specialties Center (DSC) have been set up. These centers are classified in the Brazilian Registry of Health (BRHE) as specialized clinic or outpatient specialty and are responsible for public medium-complexity assistance ${ }^{4}$. They can perform in 3 distinct categories: DSC type I (with 3 dental chairs), type II (with 4 to 6 dental chairs) and type III (with 7 or more dental chairs) ${ }^{5}$.

The DSC must work 40 hours a week and offer, minimally, advanced oral diagnostic actions, specialized periodontics, minor oral surgery, Endodontics and service to people with special needs ${ }^{6}$. Other procedures can be made available in these Centers such as prosthetic rehabilitation, orthodontic treatment and dental implants in accordance with the demands of the welfare population?

As the Smiling Brazil, the DSC represent a social achievement of the universal right to health. This right claims arising from health reform movement in the years 70, national oral health conference (NOHC), initiated in $1986^{\circ}$, and latest events in our history. Such events are the disclosure of the document "Zero hunger and mouth full of Teeth" and the conclusion of the epidemiological survey Oral Health Brazil 2003.

In essence, the "Zero Hunger and teeth-filled mouth" sought to link the need for an appropriate oral health condition to the priority on the political agenda of the current Government, the fight against hunger. So, the idea that it was necessary to have teeth to chew and reduce hunger in Brazil wins political force ${ }^{9}$. In turn, the Oral
Health Brazil 2003 highlights the morbidity from the precarious access of significant portion of Brazilians to dental care as early dental loss ${ }^{10}$.

Disability access comes from an excluding policy before the Brazilian Unified National Health System (BUNHS), when assistance actions were aimed primarily at children and the elderly and adult population were restricted to emergency services. Thus, prevailed a mutilator assistance model with low resolution ${ }^{8}$. The consequences of this care model are still present in the population which concentrates considerable levels of young people with dental loss and edentulous seniors without access to rehabilitation ${ }^{11}$.

In view of the social role of DSC on reducing inequities in access to specialized dental services and thus provide reductions in morbidity related to oral health, these services should be evaluated for the continuous improvement of its performance. However, there wasn't, until then in Brazil, DSC evaluation policy. Recently, in February 2013, the federal Government expanded the national program for the improvement of accessand quality (NPIAQ) to the DSC (DSCNPIAQ) as a strategy for qualification of specialized services in oral health ${ }^{12}$. However, in its first phase, the evaluation will continue based on the productivity of these centers. In this way, there is no consistent methodologies then able to identify weaknesses and potentialities that serve as subsidy for the management ${ }^{13}$.

Nevertheless, in the scientific literature there is a paucity of studies about oral health assessment in the specialized attention, according to the results of the study of Colussi and Calvo ${ }^{14}$. These authors conducted a systematic review of evaluation studies of oral health in electronic databases, in October 2009, and found only four studies evaluating aspects relating to centers of dental specialties, being two dissertations ${ }^{15,16}$ and two articles ${ }^{17,18}$.

In this way, the aim of this work is to analyze the performance assessment studies of dental specialties centers to thus identify factors possibly related to the performance of these centers.

\section{Method and results}

In an attempt to explore the panorama of publications about evaluation of oral health services, within the framework of secondary attention, 
an integrative review in electronic database was performed.

First, a search was held in the Lilacs database, in the period from June to October 2013, to verify the amount of publications focusing on the DSC, regardless of the purpose of the publication include the evaluation of services. The following was done reading the titles and summaries to review if the publications could encompass the theme of evaluation services in DSC, more specifically the assessment of performance.

A search performance evaluation considering the economic factors, educational and social inequalities that influence in achieving the goals and objectives of health services ${ }^{19}$. This is because the performance refers to the range of targets, the adaptability, maintenance and creation of new organizational values; the generation of quality products in accordance with established plans; and relevant indicators ${ }^{20}$. Therefore, an assessment of health services under the focus of the performance, you can size the quality of services provided and their variation between geographical areas and social groups, as well as verifying the adherence and conformity of the service by the current legislation.

Thus, the possible performance assessment references were selected for full read and verify that attended, in fact, the criterion for inclusion. If the reference had as objective the evaluation of DSC performance, this would be included in the Integrative review.

It was subsequently performed a search on MedLine database. Thus, it was conduced the reading of the titles and summaries of references found in MedLine to verify that the objective of the study was the evaluation of secondary oral health care services or the construction of evaluation instruments for this level of attention.

However, from the 51 references collected by 3rd search strategy, only 01 answering search objectives $^{21}$. As for the fourth strategy, from the 20 references, only 01 addressed the theme of evaluation of oral health services specialists, because it is a review of the literature conducted in order to identify the studies published and indexed on the evaluation of dental care in the databases BBO, Lilacs, MedLine and SciELO, in October $2009^{14}$. In turn, the fifth strategy identified the article from Goes et al. ${ }^{21}$ as the third strategy. However, such reference had already been captured in the Lilacs (strategy 3). Therefore, the total of the references $(n=13)$ included in this review were captured in Lilacs data base.

The search strategies used in Lilacs and MedLine databases, as well as the quantification of the references found, selected, deleted and included in this integrative review are described in Figure 1.

In turn, the identification of the selected references that subsidize this integrative review discussion is present in Chart 1.

In addition to these references, other subsidized the discussion of this study. Thus, Deitos ${ }^{15}$, Souza ${ }^{16}$ and Martelli ${ }^{22}$ were captured through Colussi and Calvo (2012) ${ }^{14}$ and Zaitter et al. ${ }^{23}$ were referenced by studies obtained in search strategy that met the inclusion criteria. Finally, Fortuna $^{24}$, captured on search strategy, although they do not constitute performance assessment study of DSC per se, was quoted in the discussion by addressing issues relevant to the theme of the performance.

\section{Discussion}

The references collected used different approaches to measuring the performance of the DSC. Including, 06 references use assessment tools developed specifically for performance of DSC; the Global Compliance Indicator Targets-GCIT ${ }^{17}$ and the questionnaire for evaluating the quality of oral health services - QEOHS ${ }^{25}$.

We must emphasize that the DSC, created in 2005, are relatively recent health services. However, we observed a tendency of growth of publications that have the DSC as object in view of its social relevance and the expansion of the evaluation services in governmental political agendas. In Brazil, the most current Government initiative is the establishment of the DSC-NPIAQ. However, it is necessary to continue research about the DSC and other health services, since evaluation is an ongoing process that needs to respond to current needs, management of health professionals and the general public, and these needs are in a constant process of change.

From this point of view, searches can find weaknesses in the work process of the services that compromise their organizational mission. Thus, contribute to an update of evaluative instruments like the DSC-NPIAQ ${ }^{12}$. In addition, searches can and should address aspects of the territories where the DSC are located, given the 


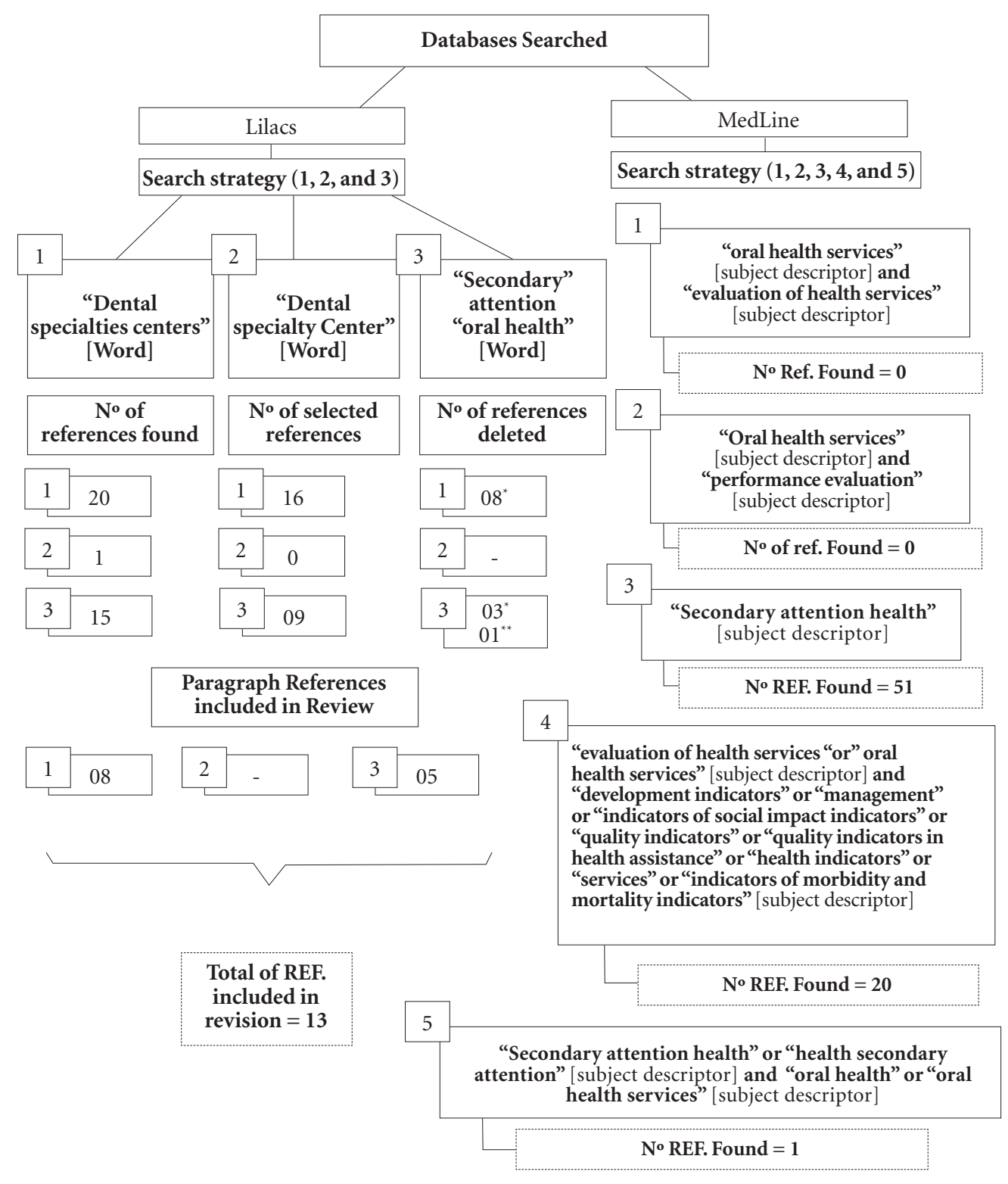

Figure 1. Flowchart of the process of selection of scientific literature.

"References deleted after full reading where watched not dealing with performance evaluation of DSC. ${ }^{* *}$ Deleted References have already been captured by strategy 01 .

assumptions of the BUNHS planning policy in making a local planning and ascendant ${ }^{26}$.

In fact, since the creation of the DSC, there is a growing expansion on your quantity throughout the Brazil. However, there is still a pattern of concentration in the Northeast and Southeast. In fact, these regions are the most populous of Bra$\mathrm{zil}^{27}$. Currently, in 2013, there are 890 DSC, being 352 in the Northeast, 317 in the Southeast, 105 in the South, in the Midwest and 6353 North $^{28}$. 
Chart 1. Selected references in the databases Lilacs in October 2013 whose goal was the evaluation of CEO performance.

\begin{tabular}{|c|c|c|c|}
\hline $\begin{array}{c}\text { Author/year/type } \\
\text { of publication }\end{array}$ & Title & Goal & $\begin{array}{c}\text { Instrument/performance } \\
\text { evaluation Forms }\end{array}$ \\
\hline $\begin{array}{l}\text { Machado et al. } \\
(2013)^{29} / \text { scientific } \\
\text { article }\end{array}$ & $\begin{array}{l}\text { Daily difficulties associated } \\
\text { with dentures }\end{array}$ & $\begin{array}{l}\text { Evaluate the } \\
\text { rehabilitation service } \\
\text { of DSC of a region of } \\
\text { Rio Grande do Norte } \\
\text { (RN) from the daily } \\
\text { difficulties associated } \\
\text { with conventional } \\
\text { total prosthesis (PTC) } \\
\text { produced between } 2007 \\
\text { and } 2009 \text {. }\end{array}$ & $\begin{array}{l}\text { Instrument/performance } \\
\text { evaluation Forms } \\
\text { Indicator: Impacts on Daily } \\
\text { Oral Performances (OIDP) Oral } \\
\text { Health Brazil } 2010 \text { Criterion to } \\
\text { assess the technical quality of the } \\
\text { prosthesis }^{30} \text {. }\end{array}$ \\
\hline $\begin{array}{l}\text { Herkrath et al. } \\
(2013)^{31} / \text { scientific } \\
\text { article }\end{array}$ & $\begin{array}{l}\text { Performance of dental } \\
\text { specialties centers outside } \\
\text { the demographic picture } \\
\text { of the municipality of } \\
\text { Amazonas, Brazil, } 2009 \text {. }\end{array}$ & $\begin{array}{l}\text { Evaluate the } \\
\text { performance of the } \\
\text { DSC of the Amazonas } \\
\text { State, considering } \\
\text { the structure of } \\
\text { establishments, covering } \\
\text { the basic care and socio- } \\
\text { demographic indicators } \\
\text { of the municipalities. }\end{array}$ & $\begin{array}{l}\text { Indicator developed by } \\
\text { Figueiredo and Góes }{ }^{17} \text { named } \\
\text { Global Fulfillment of the goals. }\end{array}$ \\
\hline $\begin{array}{l}\text { Costa et al. } \\
(2013)^{32} / \text { scientific } \\
\text { article }\end{array}$ & $\begin{array}{l}\text { Technical quality and } \\
\text { satisfaction related to } \\
\text { dentures. }\end{array}$ & $\begin{array}{l}\text { Evaluate the provision } \\
\text { of conventional total } \\
\text { prosthesis from the } \\
\text { perspective of technical } \\
\text { quality and satisfaction } \\
\text { related to this product. }\end{array}$ & $\begin{array}{l}\text { Oral Health Brazil } 2010 \text { criterion } \\
\text { to assess the technical quality of } \\
\text { prosthesis }^{30} \text { Sato et al. }{ }^{33} \text { survey on } \\
\text { satisfaction validated by Cunha }{ }^{34}\end{array}$ \\
\hline $\begin{array}{l}\text { Lima et al. } \\
(2010)^{18} / \text { scientific } \\
\text { article }\end{array}$ & $\begin{array}{l}\text { Satisfaction of users of } \\
\text { centers assisted dental } \\
\text { specialties of the city of } \\
\text { Recife, Pernambuco, Brazil. }\end{array}$ & $\begin{array}{l}\text { Assess the user } \\
\text { satisfaction assisted in } \\
\text { DSC of Recife/PE as the } \\
\text { dimensions of quality } \\
\text { for assessment of oral } \\
\text { health services. }\end{array}$ & $\begin{array}{l}\text { Questionnaire for evaluating the } \\
\text { quality of oral health services }{ }^{25} \text {. }\end{array}$ \\
\hline $\begin{array}{l}\text { Araújo et al. } \\
(2012)^{35} / \text { scientific } \\
\text { article }\end{array}$ & $\begin{array}{l}\text { Secondary attention } \\
\text { in oral health and the } \\
\text { implementation of dental } \\
\text { specialties in a northeastern } \\
\text { State, Brazil. }\end{array}$ & $\begin{array}{l}\text { Describe the } \\
\text { implementation and the } \\
\text { provision of care at DSC } \\
\text { of Ceará. }\end{array}$ & $\begin{array}{l}\text { Data from the SIA SUS and the } \\
\text { State Secretariat of Health of } \\
\text { Ceará about situational diagnosis } \\
\text { of the DSC }\end{array}$ \\
\hline
\end{tabular}

it continues

Specifically, the Northeast region concentrated both the largest number of DSC as of family health teams.
Thus, we could infer that the equity principle has guided the dissemination of these centers because the Northeast concentrates big deficiencies 


\begin{tabular}{|c|c|c|c|}
\hline \multicolumn{4}{|c|}{ Chart 1. continuation } \\
\hline $\begin{array}{c}\text { Author/year/type } \\
\text { of publication }\end{array}$ & Title & Goal & $\begin{array}{c}\text { Instrument/performance } \\
\text { evaluation Forms }\end{array}$ \\
\hline $\begin{array}{l}\text { Goes et al. } \\
(2012)^{21} / \text { scientific } \\
\text { article }\end{array}$ & $\begin{array}{l}\text { Secondary care assessment } \\
\text { in oral health: a research } \\
\text { in Brazil's specialty centers }\end{array}$ & $\begin{array}{l}\text { Evaluate secondary oral } \\
\text { health attention of the } \\
\text { DSC. }\end{array}$ & $\begin{array}{l}\text { Indicator: Global Compliance } \\
\text { Goals }\end{array}$ \\
\hline $\begin{array}{l}\text { Chaves et al. } \\
(2011)^{36} / \text { scientific } \\
\text { article }\end{array}$ & $\begin{array}{l}\text { Assessment of the } \\
\text { supply and use of dental } \\
\text { specialties in secondary } \\
\text { care services in the State of } \\
\text { Bahia, Brazil. }\end{array}$ & $\begin{array}{l}\text { Evaluate the supply and } \\
\text { use of the services of } \\
\text { four DSC of Bahia and } \\
\text { propose an ambulatory } \\
\text { production standard by } \\
\text { specialties. }\end{array}$ & $\begin{array}{l}\text { SIA-SUS data when being } \\
\text { confronted the available supply } \\
\text { and use; semi-structured } \\
\text { interview and on-the-spot } \\
\text { observation of the service. }\end{array}$ \\
\hline $\begin{array}{l}\text { Chaves et al. } \\
(2010)^{37} / \text { scientific } \\
\text { article }\end{array}$ & $\begin{array}{l}\text { National oral health } \\
\text { policy: factors associated } \\
\text { with the completeness of } \\
\text { the care. }\end{array}$ & $\begin{array}{l}\text { Analyzing factors related } \\
\text { to completeness in } \\
\text { oral healthcare DSC } \\
\text { in accordance with the } \\
\text { principles of BNOHP. }\end{array}$ & $\begin{array}{l}\text { Interview with DSC of services } \\
\text { users with questions concerning } \\
\text { the main factors associated with } \\
\text { the use of services. }\end{array}$ \\
\hline $\begin{array}{l}\text { Figueiredo and } \\
\text { Goes }(2009)^{17}\end{array}$ & $\begin{array}{l}\text { Construction of secondary } \\
\text { attention in oral health: } \\
\text { a study about the centers } \\
\text { of dental specialties in } \\
\text { Pernambuco, Brazil }\end{array}$ & $\begin{array}{l}\text { Assess dental specialties } \\
\text { centers of Pernambuco } \\
\text { from the data of SIA- } \\
\text { SUS }\end{array}$ & $\begin{array}{l}\text { Indicator: Global Compliance } \\
\text { Goals }\end{array}$ \\
\hline $\begin{array}{l}\text { Chaves et al. } \\
(2012)^{38}\end{array}$ & $\begin{array}{l}\text { Features of access and } \\
\text { use of dental services in } \\
\text { medium-sized cities }\end{array}$ & $\begin{array}{l}\text { Describe the main } \\
\text { features of access } \\
\text { and utilization of } \\
\text { basic dental services } \\
\text { and specialized in } \\
\text { two medium-sized } \\
\text { municipalities in Bahia } \\
\text { with } 100 \% \text { coverage } \\
\text { of the family health } \\
\text { Strategy. }\end{array}$ & $\begin{array}{l}\text { Variables analyzed: oral health } \\
\text { perceived need, the demand for } \\
\text { the service, the organizational } \\
\text { access barrier and the type of } \\
\text { service and the procedure used. }\end{array}$ \\
\hline $\begin{array}{l}\text { Bulgareli et al. } \\
(2013)^{39}\end{array}$ & $\begin{array}{l}\text { Secondary care } \\
\text { information in dentistry } \\
\text { for evaluation of models } \\
\text { of health care. }\end{array}$ & $\begin{array}{l}\text { Assess the basic } \\
\text { attention models } \\
\text { existing oral health in } \\
\text { the city of Marília/SP } \\
\text { through information } \\
\text { regarding secondary } \\
\text { attention in dentistry, } \\
\text { in accordance with } \\
\text { the principle of } \\
\text { completeness. }\end{array}$ & $\begin{array}{l}\text { Analyzed variables: amount of } \\
\text { referrals that are scheduled to the } \\
\text { specialties of the DSC, number } \\
\text { of patients defaulting on initial } \\
\text { consultation and number of } \\
\text { patients who left the specialized } \\
\text { treatment. }\end{array}$ \\
\hline
\end{tabular}

it continues

in oral health and unfavorable social indicators. However, under this principle, the northern region would be with a deficit in the amount of
$\mathrm{DSC}^{4}$. However, in addition to the question relating to the equity, the highest concentration of DSC in the Brazilian Northeast would be related 


Chart 1. continuation
\begin{tabular}{|l|l|l|l|}
\hline $\begin{array}{l}\text { Author/year/type } \\
\text { of publication }\end{array}$ & \multicolumn{1}{|c|}{ Title } & \multicolumn{1}{|c|}{ Goal } & \multicolumn{1}{|c|}{$\begin{array}{l}\text { Instrument/performance } \\
\text { evaluation Forms }\end{array}$} \\
\hline $\begin{array}{l}\text { Magalhães et al. } \\
(2012)^{40}\end{array}$ & $\begin{array}{l}\text { Compliance assessment } \\
\text { of secondary oral health } \\
\text { attention }\end{array}$ & $\begin{array}{l}\text { Evaluate compliance } \\
\text { with secondary oral } \\
\text { health care in the State } \\
\text { of Pernambuco, in the } \\
\text { DSC }\end{array}$ & $\begin{array}{l}\text { Indicator: Global Compliance } \\
\text { Goals }\end{array}$ \\
\hline $\begin{array}{l}\text { Figueiredo } \\
(2010)^{41} / \text { Thesis }\end{array}$ & $\begin{array}{l}\text { Centers of dental } \\
\text { specialties, DSC: a baseline } \\
\text { study for evaluation and } \\
\text { monitoring services for } \\
\text { the Northeast region }\end{array}$ & $\begin{array}{l}\text { Draw a line for the } \\
\text { base evaluation and } \\
\text { monitoring of dental } \\
\text { specialties in the } \\
\text { Northeast }\end{array}$ & $\begin{array}{l}\text { Indicator: Global Compliance } \\
\text { goals, DSC management } \\
\text { Questionnaire to analyze the } \\
\text { appropriateness of the structure } \\
\text { and process Questionnaire }{ }^{25}\end{array}$ \\
\hline
\end{tabular}

Source: authors.

to its pioneering in setting public health policies in Brazil, which served as a foundation for the development of $\mathrm{BNOHP}^{4}$.

Returning the discussion regarding fairness in the distribution of DSC, there are studies that contradict this placement. According to these studies, most of the DSC were deployed in municipalities that concentrated large demographic, best human development index (HDI) ${ }^{4,17,21}$ and also better oral health. Thus, it was observed an inverse relationship between the number of existing Centers and unfavorable social conditions, as well as between the number of DSC and need of oral health/specialized attention ${ }^{4}$.

This phenomenon, in which most services tends to achieve population coverage that less require your intervention was described by Hart as "reverse assistance law" ${ }^{42}$. But, we must emphasize that studies contrary to the equity argument used different criteria regarding the classification of population'sports of municipalities (Table 1).

The discussion of population size is relevant, because the effective functioning of DSC depends on an adequate interface primary health care (PHC) - DSC. This interface in smaller municipalities is very dependent on the agreement of consortia with other municipalities or regions to ensure the flow of referral and counter-referral.

In this sense, the ordinancesthat guided the BNOHP guidelines define the proposed deployment of units type DSC and Regional laboratory of Prosthodontics (RLP) should introduce con- sistency with the Regionalization Management Plan (RMP) of the State, and must be reference to the own municipality, region or micro- regionhealth ${ }^{5}$.

At this point is relevant to address Fortuna ${ }^{24}$ as far as your question about the conformity of regional distribution of DSC with the guideline of the regionalization of the BUNHS. According to Fortuna ${ }^{24}, 77 \%$ of the municipalities with DSC and/or RLP in Brazil have up to 100,000 inhabitants. However, from these $77 \%$, 35\% are municipalities of up to 25,000 inhabitants. As for the DSC, $62 \%$ of these units are located in the municipalities of up to 100,000 inhabitants. Of that amount, $19 \%$ are in very small municipalities (up to 25,000 inhabitants).

The number of DSC in small municipalities should be analyzed with caution, since the proper functioning of these centers depends on settlements for formation of buccal health Attention networks laid down in the RMP. If this deployment is not foreseen and planned at the regional level, this indicates not only that the principles of economy of scale are not being observed, but also the operational and financial viability of these DSC can be severely compromised. This is because the DSC must achieve goals established by the Ministry of Health in number of procedures by which is maintained its financial incentive of costing ${ }^{24}$.

However, the results of Fortuna ${ }^{24}$ revealed that few States have predicted the supply plan- 
Table 1. Classification of municipalities about demographic ports adopted by evaluation studies of dental specialties.

\begin{tabular}{|c|c|c|c|}
\hline $\begin{array}{l}\text { Municipality } \\
\text { according to } \\
\text { population size }\end{array}$ & $\begin{array}{l}\text { Figueiredo e Goes }{ }^{17} / \\
\text { Goes et al. }\end{array}$ & Saliba et al. ${ }^{4}$ & Fortuna $^{24}$ \\
\hline Too small & Up to 30 Thousand inhabitants & ----- & Up to 25,000 inhabitants \\
\hline Small & Between 30-50 thousand inhabitants & Up to 10,000 inhabitants & 25,000 to 100,000 inhabitants \\
\hline Medium & $\begin{array}{l}\text { Between } 50-100 \text { thousand } \\
\text { inhabitants }\end{array}$ & $\begin{array}{l}\text { Between 10,001 and 50,000 } \\
\text { inhabitants }\end{array}$ & $\begin{array}{l}\text { From } 100,001 \text { to } 500,000 \\
\text { inhabitants }\end{array}$ \\
\hline Big & Above 100000 inhabitants & More than 50,000 inhabitants & Over 500,000 inhabitants \\
\hline
\end{tabular}

Source: authors.

ning of DSC units in their RMP, or in other regionalized management instrument, identifying the referral flows. Thus, the massive accreditation units in small and very small municipalities, indicates a serious problem within the BNOHP; the weakness in planning the supply of DSC.

In this sense, there is congruence with the findings of studies of DSC performance where the larger population, greater HDI regions and classified as headquarters of micro-region or headquarters of module in the RMP, presented best outcome $e^{17,21}$. Thus, it was observed that compliance with secondary attention had the highest percentage (67.5 percent) in the municipalities that are reference to medium complexity, as opposed to counties that are not reference ${ }^{21}$. This finding was also found by Araújo et al. ${ }^{35}$, whose study identifies that the DSC of Ceará state obtained a higher productivity, according to the Outpatient Database of the Unified National Health System(SIA-SUS) in relation to municipal DSC.

As for the the results of Figueiredo and Goes ${ }^{17}$, Fortune $^{24}$ argues that the better performance of DSC located in larger municipalities and headquarters of micro-region and assistance models is possibly related to the fact that these DSC have been planned and agreed upon as landmarks, being targeted for demands large. So, they wouldn't have found difficulties in fulfilling goals, which were the criteria for performance analysis.

Therefore, the decentralization of health services, especially the municipalization, is placed as an important factor to minimize health inequalities and rationalize resources ${ }^{21}$. Establish health care Networks that could allow the proper inter- face $\mathrm{PHC} /$ Secondary Attention would be important factor to a greater productivity of the DSC and, to this end, we should deploy regional DSC in micro-regions health ${ }^{35}$.

This interface concerns in the $\mathrm{PHC} / \mathrm{sec}-$ ondary Attention integration on supply and fulfilment of services to the population. Such integration receives wide attention in the recent reform of European health systems with initiatives to strengthen primary health care. In these countries, the possible ways of interfacing with secondary attention, exceed the traditional referrals to procedures, encompassing the common definition of management protocols of cases until the development of shared care programs among specialties and basic network profession$\mathrm{als}^{37}$. This is because an ideal interface includes access to secondary attention (SA) of all cases referenced without barriers; these references are not relevant procedures related to $\mathrm{PHC}$ and occur in a timely manner. And yet, that after the referral made effective the counter- referral to PHC and that continues the healthcare routines in patients under long specialized treatment on $\mathrm{PHC}^{38}$.

This interface PHC/SA, summarizes how the DSC should work, since the treatment offered in these units is a continuity of the work done by the network of primary health care. In the case of municipalities that are in the family health strategy (FHS), by oral health teams (OHT). Primary care practitioners are responsible at first patient care and the referral to dental specialty Centers, if the need arise, through the referral sheets.

Once completed the treatment in these centers, the individual must be counter-referral to the basic attention, for attending activities of 
health promotion and protection ${ }^{6}$. Therefore, we could assume that greater coverage by family health teams, potential access to DSC upon referrals and thus its production. However, studies have shown controversial results ${ }^{17,21,31,37}$.

In studies conducted by Figueiredo and Goes ${ }^{17}$ and Goes et al. ${ }^{21}$, municipalities with population coverage by the FHS exceeding 50\% (condition prevalent in the municipalities of medium and large companies) had the worst performances of DSC, result other than Chaves et al. study ${ }^{37}$. In turn, the study of Herkrath et al. ${ }^{31}$, which aimed to assess the performance of the DSC of the Amazonas State, considering the structure of establishments, covering the basic care and socio-demographic indicators of the municipalities, also found that counties with higher coverage of FHS/ OHT presented the worst performances. These authors used the same instrument of analysis from Figueiredo and Goes ${ }^{17}$ and Goes et al. ${ }^{21}$. However, their study presented descriptive approach.

In turn, Chaves et al. ${ }^{31}$ verified factors related to the completeness which, in turn, can be understood as a proxy of DSC's performance in oral healthcare. Completeness was checked by the reporting of realization of basic dental treatment before or concomitant to specialized treatment by the user. The coverage of the family health pro$\mathrm{gram} /$ oral health team (FHP/OHT) in the municipality was considered a covariate health system could influence the guarantee of completeness. As an outcome, the study concluded that the ease of geographical access, presence of user referral sheet from the PHC and FHP coverage $\geq 50 \%$ influenced positively for completeness. And yet, that DSC deployment in municipalities in which the PHC is not properly structured is not recommended, because the secondary attention would be attending a free demand and running basic procedures and thus not fulfilling the principle of completeness required. The authors pointed out as limitation of their study the fact that they investigated only people who accessed the services of DSC (sample of demand), rather than also include those who have not accessed the service in such a way as to constitute a population-based sample.

In turn, Figueiredo and Goes ${ }^{17}$ and Goes et al..$^{21}$ used for measuring performance of DSC the scorecard, "Global Compliance Indicator Targets of DSC", obtained from the quotient resulting from the monthly average of procedures performed of each subgroup of dental specialties (basic care procedures; Periodontics; Endodontics; Oral Surgery Less) by the number of procedures corresponding to the target of this subgroup multiplied by 100 registered ${ }^{17}$. The data relating to procedures have been taken from the SIA-SUS and the goals established in accordance with Ministerial Decree regulating the minimum production per type of DSC, in case the Ordinance No. 600 of $2006^{43}$. Goal achieved, was considered the services fulfilled percentage equal to or greater than $100 \%$ standardized target for each subgroup. Under such perspective, the performance of services was ranked in: bad performance (DSC has not met any target); poor performance (DSC fulfilled just 1 goal); regular performance (DSC fulfilled 2 goals); good performance (DSC fulfilled 3 goals); and optimum performance (DSC fulfilled all the goals).

The use of secondary data from SIA-SUS, subject to consolidation errors, and also the use of an indicator whose performance rating parameter is the fulfillment of goals stipulated in ordinances which consider only the type of DSC (I, II and III), and not the potential offer of specialties procedures, were singled out by Chaves et al ${ }^{37}$ as probable reasons for different results.

However, later study Chaves et al. ${ }^{38}$, seeking to overcome the limitation of earlier study $y^{37}$, sought to describe the main features of access and utilization of basic and specialized dental services in two medium-sized municipalities in Bahia with $100 \%$ coverage of the FHP through the composition of a population-based sample. In this study, the use was understood as act of joining and as a result of the interaction between the behavior of the individual who needs professional care which leads, within the health service system and the characteristics of this, and "form of entry into the health system, to perform procedures, diagnostic, therapeutic or rehabilitative". In turn, access is understood as the characteristics of the services that allow them to be more easily used by users, including accessibility as a synonym.

Among their findings, Chaves et al. ${ }^{38}$ pointed out that there was no relevant barrier to access the specialized public attention, given that less than $2 \%$ of individuals in two municipalities evaluated did not received care. This has given rise to the hypothesis that the main barrier to access could be located in primary care. According to this hypothesis, the authors put the FHS/ OHT has the greatest potential to increase access to health services outside the traditional technical assistance model. However, it is necessary to examine to what extent the greater access to primary health care can mean better outcome to cases requiring other levels of complexity of the health system. 
Thus, the authors pose that their study reinforces the hypothesis that the main barrier to access is on PHC and not on specialized atten$\operatorname{tion}^{36}$. That is, their analyses are congruent with the findings of Figueiredo and Goes ${ }^{17}$, Goes et al. ${ }^{21}$ and Herkrath et al. ${ }^{31}$, whose studies have concluded that municipalities with lower family health coverage achieved best performances of DSC.

The greatest population coverage analysis for OHT and worst performance of DSC was also held by Fortuna ${ }^{24}$, attributed this relationship to the lower population size of the municipality and not to the population coverage itself. This is because smaller municipalities hold best toppings for OHT and, in General, do not represent reference municipalities to medium complexity, which would compromise the fulfillment of quantitative targets as already explained previously.

Verification of the greater ease of implantation of the FHP in small municipalities took place in important studies as the research "evaluation of the Implementation of the family health program in big urban centers-ten case studies". Such research has detected problems groups in the implementation of the FHP in large municipalities: difficulties of replacing the traditional model of primary health care; obstacles in the integration and development of human resources; difficulties with regard to the monitoring of the process and results of the program; concerns about the integration of the PHC to other levels of complexity ${ }^{44}$.

Therefore, it is necessary to study alternatives for overcoming the barriers of access to public dental assistance. In General, studies have revealed a low resolution of problems in the basic attention and persistence of traditional models of access to services, where problems persist as long queues of ${ }^{32}$.

As for the attention of the DSC, discusses the increasing access and reducing waiting lines could occur through reorganization of the patient flow and work processes. Such a reorganization if Sue by the inclusion of alternatives such as the implementation of prior consultations and scheduling a daily waiting list for replacement of absentees or extra markup, considering the probable lack of pacientes $^{36}$. And yet, it is suggested the central deployment of appointments, use of protocols and reference instruments and investment in information technology, respect to the flow of routing and increasing the clinical query time $e^{13,41,45,46}$.

The establishment of an active query markup is seen as a way to regulate the supply and demand of health services ${ }^{2}$. This is because, in the area of health, the concept of regulation is related to aspects of organizing the flow of patients at various levels of the BUNHS. Therefore, regular in health refers to the task of disciplining, establish rules, order, steer and organize the flow of patients in the health system ${ }^{47}$. Already the increase in query time clinic, would reduce the number of trips to the DSC and, consequently, the costs to the user, decreasing the faults and empowering the chances of increasing productivity ${ }^{38}$. Moreover, it could provide more time for the patient listener and thus greater user satisfaction ${ }^{18}$.

In fact, the above mentioned factors are relevant to the performance of the DSC, since study aiming to assess the rate of use of the services of these centers has identified a low utilization rate. The factors related to this finding would be barriers to access health service itself, such as the lack of a system of automatic waiting list for replacement of absentees, the absence of reference/ protocols, lack of standardization in the operative techniques used by dentists, non-compliance with the real working hours, lack of a management system with a clear definition of goals of offering specialty procedures and the realization of basic procedures of $\mathrm{PHC}$ in the $\mathrm{DSC}^{36}$.

In fact, two studies indicate that the use of protocols and the appointment of queries, as well as the imposition of a regulatory central are successful alternatives for improvement of services of the DSC ${ }^{23,48}$. According to Zaitter et al..$^{23}$, the exam with sorting character performed by the dentist in individuals that potentially need Endodontic therapy, using pre-established criteria in Protocol, enables a appointments according to the individual's vulnerability and capacity for work of the service. After sorting (pre-assessment), schedule-if the query, depending on the availability of day and time of the user; confirmed scheduling transfers-if your queue name entered for specializes in Endodontics. In addition, it is made a constant updating of the register of individuals who demand endodontic treatment, with changes of address, occurrence of deaths or the carrying out of treatment in other services.

In relation to the appointments, Pereira et al..$^{48}$ demonstrate a reduction in waiting time for appointments in the DSC, due to use of an online system of marking. Such indicates Health centers (HC) vacancies for scheduling in dental specialties in health administrative regions. These vacancies are available one day a week and are distributed by "quotas" for each HC, being that the basic units are responsible to enter the system and schedule their patients. Vacancies un- 
filled enter again in the system and are distributed by order of access to the system.

However, the authors were obstacles to the proper functioning of the marking system. These barriers were related to unethical mechanisms health centers in repeat names of individuals for the same procedure, in order to "save" vacancy in the system. This reinforces the need to adapt rules and criteria for the implementation and monitoring of effective protocols and reference. In addition, it was also found that, for the vacancies occupied initially, the units that come first in the scheduling system would be the most benefited, not prioritizing access to who else needed. In this way, going against the principle of fairness, since there was an evaluation of the socioeconomic variables and pent-up demand.

In this way, the essential is to develop work processes that enable the formation and operation of a network of buccal health attention ${ }^{13,45,46}$. Otherwise, persist a fragmented health care model in which the system services do not fit together, acting as isolated points and, consequently, do not respond to the demands of the population continuously and longitudinal ${ }^{49}$. The conformation of assistance networks is essential, since organizations and health professionals do not have all the necessary resources and expertise to the solution of all problems of health of a popula$\operatorname{tion}^{50}$. Therefore, its implementation enhances efficiency, rationality, and access services ${ }^{51}$.

In relation to the target population of the services of the DSC, one realizes that, although they are geared to receive any individual, there is a profile of the population which concentrates its use. According to the study conducted by Lima et al. ${ }^{18}$ in DSC of Pernambuco, users were between the ages of 18 and 74 years $(40.8 \%$ between 31 and 50 years and $40.4 \%$ between 18 and 30 years old). Most were women (73.9 percent), Browns (51.8 percent), living only (60.3\%) and with the level of education to the elementary school (54 percent). As for the job/income, it was evidenced that the majority (46 percent) had a sporadic work, with equities.

Similar profile of users was found by Chaves et $\mathrm{al}^{38}$ in DSC of Bahia population mid-sized municipalities. Thus, the results of these studies are congruent with those of the Oral Health Brazil 2010, which found that, in fact, the adult population (35-44 years) is having a greater access to dental services ${ }^{11}$. That would have implications in reducing tooth loss in this population.

The study of the profile of users is important, because it may influence the satisfaction of same with the service. According to Lima et al. ${ }^{18}$, the fact that the users of DSC belong mostly to lower socioeconomic classes can provide a bias of gratitude (gratitude bias) in connection with the services and products made available to the population. In this sense, it is necessary to investigate, in addition to user satisfaction with the treatment or product, the technical quality and functionality of the same to the user life ${ }^{24,21}$. This is because, when considering the level of user satisfaction, the evaluation of the quality of health care should assess the service adjustment to demand and be able to detect the extent to which this service meets the expectations of the patient ${ }^{18}$.

Under this prerogative, Costa et $\mathrm{al}^{32}$, when assessing full conventional dentures (FCD) made in CEO about technical quality and user satisfaction, detected that the FCD evaluated 233, 52.7\% from $9.5 \%$ of inferior and superior were technically satisfactory. Despite this, $69.1 \%(\mathrm{n}=103)$ of respondents reported satisfaction with their prostheses. As for the functionality of these prostheses, it was observed that a sample of 138 users, $42 \%$ reported difficulties related to the FCD to perform oral activities, above all, eating, talking and smiling ${ }^{29}$.

With regard to the quality of services of the DSC, Goes et al. ${ }^{21}$ claim that one of the ways of its improvement would be the qualification of professionals, with permanent education and establishment of residence in secondary attention to formation of skills and competencies directed to DSC. In addition, it would be important to the assessment of own technologies and procedures to the DSC, and may be conducted by the establishment of Clinical Research Network, for secondary attention, and conducting research on the impact of the implementation of the DSC in Brazil $^{21}$.

Finally, it is important to address the issue of financing, since the research involving DSC point out that, in addition to the weaknesses already mentioned, there are difficulties in this aspect which can influence on its performance. According to Martelli ${ }^{22}$, federal financial incentives provided to the DSC are insufficient for their maintenance, the need for State and local counterparts as advocated legally. However, the author states that only in Ceará, Rio Grande do Sul and Santa Catarina's State allocation for the DSC.

From the perspective of performance evaluation, with greater financial resources services would tend to produce more favorable results. Thus, it is necessary to evaluate the governance and the capacity of Government of the munici- 
palities that are home to the DSC and be based on the financial transfers in accordance with their specific characteristics, such as loco-regional would be expected of a fair policy. This is because, even in the face of a proper government project (plan a team sets out to accomplish to achieve their goals), it is necessary to evaluate the variables or features that the team controls it or not and that are required to execute the plan (governance) and the experience and knowledge to the team dominates to implement your plan (capacity of Government). In this way, we would need to review the criteria for transfer that are currently carried out by type of DSC (I, II and III).

This reports the need to revise the guidelines of BNOHP, as well as to the related regulatory Ordinances to assess this and other issues. An important issue would be the greater rigidity to the presence of a PHC services as a decisive criterion for deploying units of DSC and RLP ${ }^{24}$. Because, as we previously, the services in their respective health care levels need to work as a health care Network, where every point of this network have specific assignments for the scope of the efficaciousness of attention.

However, the study conducted by Fortuna ${ }^{24}$ reveals that there are regions in Brazil where there's only presence of RLP. According to the author, the existence at the time of the RLP 526 study, 215 (41 percent) were in counties that relied solely on this type of unit, not counting DSC. In this way, one could infer that these municipalities would not be suing the change of a model of attention to health care mutilator. This is because, probably, would be going on a soft assistance where tooth extractions would be made in the basic attention to placement of prostheses made us RLP ${ }^{23}$. However, this assertion cannot be established since specialized actions could be made available in other services, a fact not investigated.

In fact, although the DSC are more commonly known as services responsible for specialized attention in dentistry in public service, specialized attention is composed of the secondary levels of attention (medium complexity), where the DSC are inserted, and tertiary (high complexity). As for the medium complexity, in addition to the DSC, this is composed of services provided by the Urgency Dental Services (UDS) and by the Diagnosis and Therapy Service Support (DTSS). However, the DSC is the main strategy of secondary attention in Brazil ${ }^{3}$.

In addition to the result of the absence of DSC, Fortuna ${ }^{24}$ has detected that there are health regions where there is no presence of DSC. Between the Brazilian States, only five States have DSC in $100.00 \%$ of their health regions: Alagoas, Ceará, Mato Grosso do Sul, Rio Grande do Norte and Roraima. However, two of these States are listed in this category by having a low number of regional divisions: Mato Grosso do Sul (3 health regions) and Roraima (health region 1). This situation is even more critical as regards the RLP, since only Alagoas, Mato Grosso do Sul and Rio Grande do Norte have RLP in all regions of health. Again, the author caveat that Mato Grosso do Sul has only three regional divisions, which facilitates its placement in this category.

In this way, this distribution of DSC hinders the conformation of an assistance network. However, the author points out that in addition to a more homogeneous distribution of the DSC health regions, it is essential that there is a prediction of flows of patients between the municipalities, and that this prediction appears in the regionalized management instruments, with a view to securing of users from different municipalities access to specialized services in oral health ${ }^{24}$. IE is strongly the use of planning tools as the RDP to implement a health care Network for equity in health.

Given the above, we can synthesize the deployment of DSC should be held in municipalities that have the PHC appropriately structured, so that secondary attention have basis for fulfilling the principle of completeness required ${ }^{37}$. Thus, potentializing the likelihood of overcoming the barriers of access to oral health services. These barriers of diverse nature: geographical and socioeconomic organizational ${ }^{37}$. An alternative to seek solutions to overcome these barriers is to perform evaluations to support planning and decision-making. In this regard, initiatives such as the DSC- NPIAQ should be highlighted and DSC evaluation studies should be conducted, once the object of healthcare services, life and health-disease process are quite dynamic. Thus, we must reinvigorate evaluative processes continuously.

\section{Conclusion}

The performance of DSC is influenced by forms of organization and management of work processes and contextual characteristics of places where they are deployed. Generally speaking, more developed localities showed the best results according to the performance indicators 
used. And yet, the implementation of regulatory centers and the formation of consortia of health were forms of organization of assistance related to the better performance of the DSC. Moreover, studies indicate the need to introduce ways of assessing the products generated in these centers according to criteria of responsiveness. This is because the indicators of satisfaction may not necessarily reflect the quality of care of the DSC.

\section{Collaborations}

FCA Machado, JV Silva and MAF Ferreira participated in all stages of preparation of the article. 


\section{References}

1. Brasil. Ministério da Saúde (MS). Secretaria de Atenção à Saúde. Departamento de Atenção básica. Coordenação Nacional de Saúde bucal. Diretrizes da Política Nacional de Saúde Bucal. Brasília: MS; 2004.

2. Santana VGD, Lima AS, Macedo CLSV, Pimentel FC, Araújo Junior JLAC, Marte PJL. Análise da evolução e financiamento da assistência odontológica na média complexidade no município do Recife no período de 2000 a 2007. Cad. Saúde Colet 2008; 16(3):527-544.

3. Goes PSA, Moysés SJ, organizadores. Planejamento, gestão e avaliação em saúde bucal. Porto Alegre: Artes Médicas; 2012.

4. Saliba NA, Moimaz SAS, Fadel CB, Bino LS. Saúde Bucal no Brasil: uma nova política de enfrentamento para a realidade nacional. Rev Odontol Bras Central 2010; 18(48):62-66

5. Brasil. Portaria no 599, de 23 de Março de 2006. Define a implantação de Especialidades Odontológicas (CEO) e de Laboratórios Regionais de Próteses Dentárias (LRPDs) e estabelecer critérios, normas e requisitos para seu credenciamento. Diário Oficial da União 2006; 24 mar.

6. Brasil. Ministério da Saúde (MS). Centros de Especialidades e Laboratórios de Prótese dentária. [acessado 16 fev 2011]. Disponível em: http://portal.saude.gov. $\mathrm{br} /$ portal/saude/visualizar_texto.cfm?idtxt $=236468 \mathrm{ja}$ nela $=1$

7. Brasil. Ministério da Saúde (MS). Secretaria de Atenção à Saúde. Departamento de Atenção Básica. Coordenação geral de saúde bucal. Nota técnica: Portaria SAS 718. Brasília: MS; 2010.

8. Costa JFR, Chagas LD, organizadores. A politica nacional de saúde bucal do Brasil: registro de uma conquista histórica. Brasília: Organização Pan-Americana da Saúde; 2006.

9. Guerra KCM. Os Centros de Especialidades Odontológicas nos Municípios do Estado do Rio de Janeiro: Uma Investigação dos Fatores Identificáveis como Facilitadores ou Não na Implantação de Uma Política de Indução Financeira [dissertação]. Rio de Janeiro: Universidade do Estado do Rio de Janeiro; 2009.

10. Brasil. Ministério da Saúde (MS). Projeto SB Brasil 2003: condições de saúde bucal da população brasileira 2002-2003. Resultados principais. Brasília: MS; 2004.

11. Brasil. Ministério da Saúde (MS). Secretaria de Atenção à Saúde/Secretaria de Vigilância em Saúde. Departamento de Atenção Básica. Coordenação Geral de Saúde Bucal. Pesquisa Nacional de Saúde Bucal SB Brasil 2010: Resultados principais. Brasília: MS; 2011.

12. Brasil. Portaria no 261, de 21 de Fevereiro de 2013. Institui, no âmbito da Política Nacional de Saúde Bucal, o Programa de Melhoria do Acesso e Qualidade dos Centros de Especialidades Odontológicas (PMAQ-CEO) e o Incentivo Financeiro (PMAQ-CEO), denominado Componente de Qualidade da Atenção Especializada em Saúde Bucal. Diário Oficial da União 2013; 22 fev.

13. Reses MLN. Avaliação da implantação dos Centros de Especialidades Odontológicas em Santa Catarina [dissertação]. Florianópolis: Universidade Federal de Santa Catarina; 2011.
14. Colussi CF, Calvo MCM. Avaliação da Atenção em Saúde Bucal no Brasil: uma revisão da literatura. Sau. \& Transf Soc 2012; 3(1):92-100.

15. Deitos AR. Avaliação na atenção especializada em saúde bucal [dissertação]. São Paulo: Universidade de São Paulo; 2009.

16. Souza GCA. Centros de Especialidades Odontológicas: avaliação da atenção de média complexidade na rede pública da Grande Natal [dissertação]. Natal: Universidade Federal do Rio Grande do Norte; 2009.

17. Figueiredo N, Goes PSA. Construção da atenção secundária em saúde bucal: um estudo sobre os Centros de Especialidades Odontológicas em Pernambuco, Brasil. Cad Saude Publica 2009; 25(2):259-267.

18. Lima ACS, Cabral ED, Vasconcelos MMVB. Satisfação dos usuários assistidos nos Centros de Especialidades Odontológicas do Município do Recife, Pernambuco, Brasil. Cad Saude Publica 2010; 26(5):991-1002.

19. Viacava F, Almeida C, Caetano R, Fausto M, Macinko J, Martins M, Noronha JC, Novaes HMD, Oliveira ES, Porto SM, Silva LMV, Szwarcwald CL. Uma metodologia de avaliação do desempenho do sistema de saúde brasileiro. Cien Saude Colet 2004; 9(3):711-724.

20. Hartz ZMA. Meta-Avaliação da gestão em saúde: desafios para uma "nova saúde pública". Cien Saude Colet 2012; 17(4):829-837.

21. Goes PSA, Figueiredo N, Neves JC, Silveira FMM, Costa JFR, Pucca Júnior G, Rosales MS. Avaliação da atenção secundária em saúde bucal: uma investigação nos centros de especialidades do Brasil. Cad Saude Publica 2012; 28(Supl.):S81-S89.

22. Martelli PJL. Política Nacional de Saúde Bucal, da teoria à prática: um estudo de caso acerca de sua implantação em Recife-PE no período 2000 a 2007 [tese]. Recife: Centro de Pesquisas Aggeu Magalhães; 2010.

23. Zaitter WM, Silva M, Biazevic MGH, Crosato E, Pizzatto E, Michel-Crosato E. Avaliação da acessibilidade do paciente à clínica de especialidades de Endodontia em dois distritos de saúde do município de Curitiba (PR). Rev Sul-Bras Odontol 2009; 6(4):413-420.

24. Fortuna RFP. A média complexidade no quadro da Política Nacional de Saúde Bucal: uma abordagem do seu processo de desenvolvimento em uma perspectiva regional [tese]. Rio de Janeiro: Universidade do Estado do Rio de Janeiro; 2011.

25. Fernandes LMAG. Validação de um instrumento para avaliação da satisfação dos usuários com os serviços públicos de saúde bucal - QASSaB [tese]. Camaragibe: Universidade de Pernambuco; 2002.

26. Brasil. Ministério da Saúde (MS). Portaria no 2.135, de 25 de Setembro de 2013. Estabelece diretrizes para o processo de planejamento no âmbito do Sistema Único de Saúde (SUS). Diário Oficial da União 2013; 26 set.

27. Instituto Brasileiro de Geografia e Estatística (IBGE). Sinopse do Censo Demográfico 2010: População nos Censos Demográficos, segundo as Grandes Regiões e as Unidades da Federação - 1872/2010. [acessado 2014 ago 3]. Disponível em: http://www.ibge.gov.br/home/ estatistica/populacao/censo2010/tabelas_pdf/Brasil_ tab_1_4.pdf 
28. Brasil. Ministério da Saúde (MS). Brasil sorridente: Ministério da Saúde aumenta recursos para a saúde bucal [Internet]. [acessado 2013 abr 8]. Disponível em: http://portalsaude.saude.gov.br/portalsaude/noticia /5592/162/ministerio-da-saude-aumenta-recursospara-a-saude-bucal.html

29. Machado FCA, Costa APS, Pontes ALP, Lima KC, Ferreira MAF. Dificuldades diárias associadas às próteses totais convencionais. Cien Saude Colet 2013; 18(10):3091-3100.

30. Brasil. Ministério da Saúde (MS). Manual do pesquisador de campo. Projeto SB Brasil 2010. Brasília: MS; 2009.

31. Herkrath FJ, Herkrath APCQ, Costa LNBS, Gonçalves MJF. Desempenho dos Centros de Especialidades Odontológicas frente ao quadro sociodemográfico dos municípios do Amazonas, Brasil, 2009. Saúde Debate 2013; 37(96):148-158.

32. Costa APS, Machado FCA, Pereira ALBP, Carreiro AFP, Ferreira MAF. Qualidade técnica e satisfação relacionadas às próteses totais. Cien Saude Colet 2013; 18(2):453-460.

33. Sato Y, Hamada S, Akagawa Y, Tsuga K. A method for quantifying overall satisfaction of complete dentures patients. J Oral Rehabil 2000; 27(11):952-957.

34. Cunha EFS. Avaliação de prótese total bimaxilar em função das características da área basal [tese]. São Paulo: Universidade de São Paulo; 2004.

35. Araújo DB, Menezes LMB, Sousa DL. Atenção secundária em saúde bucal e a implementação dos Centros de Especialidades Odontológicas em um estado do Nordeste, Brasil. RGO 2012; 60(1):49-54.

36. Chaves SCL, Cruz DN, Barros SG, Figueiredo AL. Avaliação da oferta e utilização de especialidades odontológicas em serviços públicos de atenção secundária na Bahia, Brasil. Cad Saude Publica 2011; 27:143-154.

37. Chaves SCL, Barros SG, Cruz DN, Figueiredo ACL, Moura BLA, Cangussu MCT. Política Nacional de Saúde Bucal: fatores associados à integralidade do cuidado. Rev Saude Publica 2010; 44(6):1005-1013.

38. Chaves SCL, Soares FF, Rossi TRA, Cangussu MCT, Figueiredo ACL, Cruz DN, Cury PR. Características do acesso e utilização de serviços odontológicos em municípios de médio porte. Cien Saude Colet 2012; 17(11):3115-3124.

39. Bulgareli JV, Faria ET, Ambrosano GMB, Vazquez FL, Cortellazzi KL, Meneghi MC, Mialhe FL, Pereira AC. Informações da atenção secundária em Odontologia para avaliação dos modelos de atenção à saúde. Rev Odontol UNESP 2013; 42(4):229-236.

40. Magalhães BG, Oliveira RS, Gaspar GS, Figueiredo N, Goes PSA. Avaliação do Cumprimento de Atenção Secundária em Saúde Bucal. Pesq Bras Odontoped Clin Integr 2012; 12(1):107-112.

41. Figueiredo N. Centros de Especialidades Odontológicas, CEO: um estudo linha de base para avaliação e monitoramento dos serviços para a região Nordeste [tese]. Camaragibe: Faculdade de odontologia de Pernambuco; 2010.
42. Hart JT. The inverse care Law. Lancet 1971; 1(7696):405412.

43. Brasil. Ministério da Saúde (MS). Portaria no 600, de 23 de março de 2006. Institui o financiamento dos Centros de Especialidades Odontológicas. Diário Oficial da União 2006; 24 mar.

44. Brasil. Ministério da Saúde (MS), Fundação Oswaldo Cruz. Saúde da Família: avaliação da implementação em dez grandes centros urbanos: sintese dos principais resultados. Brasília: Editora do Ministério da Saúde; 2005.

45. Silva SF, Magalhães Júnior, HM. Redes de atenção à saúde: importância e conceitos. In: Silva SF, organizador. Redes de atenção à saúde no SUS: o pacto pela saúde e redes regionalizadas de ações e serviços de saúde. Campinas: Idisa, CONASEMS; 2008. p. 69-85.

46. Almeida PF. Estratégias de coordenação dos cuidados: fortalecimento da atenção primária à saúde e integração entre níveis assistenciais em grandes centros urbanos [tese]. Rio de Janeiro: Escola Nacional de Saúde Pública Sérgio Arouca; 2010.

47. Brasil. Ministério da Saúde (MS). Secretaria de Assistência à Saúde. Regionalização da assistência à saúde: aprofundando a descentralização com equidade no acesso: Norma Operacional da Assistência à Saúdel SUS NOAS e Portaria MS/GM no 95 de 26 de Janeiro de 2001 e regulamentação complementar. Brasília: MS; 2001.

48. Pereira AC, Vazquez FL, Guerra LM, Vitor ES, Ambrosano GMB, Mialhe FL, Meneghim MC. Referência e Contra-Referência na Atenção Secundária em Odontologia em Campinas, SP, Brasil. Cien Saude Colet 2013; 19(1):245-256.

49. Mendes EV. As redes de atenção à saúde. Cien Saude Colet 2010; 15(5):2297-2305.

50. Hartz ZMA, Contandriopoulos A. Integralidade da atenção e integração dos serviços de saúde: desafios para avaliar a implantação de um "sistema sem muros". Cad Saude Publica 2004; 20(Supl. 2):S331-S336.

51. Santos L, Andrade LOM. Redes interfederativas de saúde. In: Silva SF, organizador. Redes de atenção à saúde no SUS: o pacto pela saúde e redes regionalizadas de ações e serviços de saúde. Campinas: Idisa, CONASEMS; 2008. p. 35- 65 .

Article submitted 06/11/2014

Approved 08/17/2014

Final version submitted 08/23/2014 
